\title{
Effectiveness of pilot trial of family meal support prior inpatient discharge
}

\author{
Mei Yee Chan ${ }^{*}$, Helen Kelly \\ From 2014 ANZAED Conference: Driven Bodies Driven Brains \\ Fremantle, Australia. 22-23 August 2014
}

The North Western Mental Health Eating Disorder Program at The Royal Melbourne Hospital provides treatment for adults 18 years and over since 1994. The eating disorder program provides an in-patient and day-patient treatment program and comprehensive out-patient services.

Family members have been an effective and vital support for clients with eating disorders in their treatment and recovery in our day patient program. This pilot trial is to explore the family dynamics and confidence of family members in supporting in-patient clients with anorexia nervosa during a meal. Family members would be empowered with evidence based knowledge and strategies to support their loved ones through a meal prior to discharge as part of the discharge planning.

The theoretical framework for this trial is based on a modification of the Family-Based Therapy (FBT). In several controlled studies, it has proven that Family-Based Treatment to be successful in an out-patient setting especially for adolescent in helping individual in weight restoration.

Submit your next manuscript to BioMed Central and take full advantage of:

- Convenient online submission

- Thorough peer review

- No space constraints or color figure charges

- Immediate publication on acceptance

- Inclusion in PubMed, CAS, Scopus and Google Scholar

- Research which is freely available for redistribution
() Biomed Central

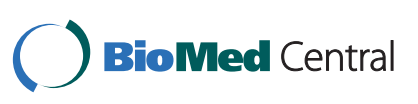

(c) 2014 Chan and Kelly; licensee BioMed Central Ltd. This is an Open Access article distributed under the terms of the Creative Commons Attribution License (http://creativecommons.org/licenses/by/4.0), which permits unrestricted use, distribution, and reproduction in any medium, provided the original work is properly cited. The Creative Commons Public Domain Dedication waiver (http://creativecommons.org/publicdomain/zero/1.0/) applies to the data made available in this article, unless otherwise stated. 